\title{
Human Retinal Extract Stimulates the Proliferation of Human Lens Epithelial Cells
}

\author{
T. J. C. JACOB,${ }^{1}$ R. C. HUMPHRY,${ }^{2}$ E. G. DAVIES ${ }^{2}$ and G. M. THOMPSON ${ }^{2}$ \\ London
}

\begin{abstract}
Summary
The proliferation of lens epithelial cells remaining attached to the capsule after extracapsular cataract extraction represents a potential cause of posterior capsule opacification. In view of the reported mitogenic effects of eye derived growth factors on lens epithelial cells in animal studies, we determined to establish whether the human retina produces a factor capable of inducing a similar response in human lens epithelial (HLE) cells. We report that an extract of the human neural retina is capable of increasing the proliferative capacity of HLE cells in culture by $50 \%$. The possible mechanisms are discussed. The presence of such a growth factor in the human eye would have important consequences for the epithelial cells remaining after cataract surgery.
\end{abstract}

Research on the bovine lens has demonstrated that the growth of bovine lens epithelial cells in tissue culture can be controlled by a growth factor derived from the adult bovine retina. ${ }^{1,2,3}$ This growth stimulating activity is found in the vitreous, ciliary body, iris and choroid but is usually prepared from the retina. ${ }^{4}$ The ubiquitous ocular location of this factor suggests that it may be an important regulator of lens embryogenesis and it is termed Eye Derived Growth Factor (EDGF). The role of EDGF in the normal homeostasis of the mature lens is unclear although in vitro experiments with cultured rat lens epithelial cells have demonstrated the ability of EDGF to stimulate elongation and differentiation into fibre cells. ${ }^{5,6}$

EDGF derived from bovine retina has been partially purified. ${ }^{7}$ It is a protein of $17,500 \mathrm{D} \pm 3,500 \mathrm{D}$ with an isoelectric point of $4.5 \pm 0.5$, has an activity 1,000 times greater than the initial crude extract and could stimulate bovine lens epithelium (BLE) cells to proliferate at a concentration of $14 \mathrm{ng} / \mathrm{ml}$ of culture medium. No differences were apparent between EDGF of the retina or vitreous body - suggesting that they both contain the same growth factor. In view of the intense interest in neovascular disorders in the eye, although outside the scope of this study, it should be mentioned that EDGF possesses an angiogenic activity ${ }^{8}$ and an angiogenic factor has been isolated from the bovine retina. ${ }^{9}$ It has been suggested that EDGF is related to, if not identical to, Fibroblast Growth Factor (FGF) since this factor stimulates lens epithelial cells to grow, ${ }^{10}$ has similar retention steps on chromatography, similar molecular weights and similar amino-acid compositions. ${ }^{11}$ Using radioimmunoassay for bovine FGF that recognises human FGF this factor has been detected in patients who have had a history of vitreous haemorrhage and multiple vitrectomy opera-

From ${ }^{1}$ Department of Pharmacology, St. George's Hospital Medical School, London, SW17 0RE. ${ }^{2}$ Department of Ophthalmology, St George's Hospital, London, SW17 0RE

Correspondence to: R C Humphry FRCS, West of England Eye Infirmary, Magdalen Street, Exeter EX2 4HT, UK 
tions. ${ }^{12}$ The authors raise the possibility that FGF may be involved in the aetiology of vasoproliferative diseases of the eye.

Bovine, rat and rabbit lens epithelial cells in culture attain much higher population doubling levels than the human. ${ }^{4,13}$ Our interest in the proliferation of lens cells results from the clinical problem of opacification of the posterior lens capsule following extracapsular cataract extraction. We have, in a previous study, demonstrated that explants of human lens epithelium can be stimulated to grow in tissue culture and that an important factor stimulating cellular proliferation from an intact basement membrane (i.e. the lens capsule) is release from contact inhibition - even in areas away from the germinative region of the equator..$^{14}$ In this study we have examined the effects of human EDGF on cultured human lens epithelial (HLE) cells.

\section{Materials and Methods}

\section{(a) Retinal extract preparation}

Neurosensory retinas were obtained from eight cadaver eyes which had been stored at $-20^{\circ} \mathrm{C}$, within 24 hours of death. Using the method described by Arruti and Courtois ${ }^{1}$ the retinas were homogenised in Dulbecco's phosphate buffered saline (DPBS) using an Ultra Turrax. After centrifugation at $11,200 \mathrm{~g}$ for 30 minutes, the supernatant was removed and passed through millipore filters $(0.45 \mu \mathrm{m}$ followed by $0.2 \mu \mathrm{m}$ ) and stored at $-20^{\circ} \mathrm{C}$.

The protein content of the retinal extract, determined by the method described by Lowry et al.,$^{15}$ was found to be $640 \mu \mathrm{g} / \mathrm{ml}$. This extract is referred to as Neuro-retinal extract (NRE).

\section{(b) Tissue Culture}

A total of 24 experimental cultures were grown from normal lens epithelia obtained from three human donor eyes within 48 hours of death (eye 1, from a donor aged 59 years; eyes 2 and 3 were from the same donor aged 75 years). Each eye was bisected equatorially behind the ora serrata and the lens removed by cutting the suspensory ligaments. Explants from each of the lenses were cultured in medium E199 with fetal calf serum (FCS), $50 \%$ for the first 10 days, reduced to
$36 \%$ on day $10,25 \%$ on day $13,10 \%$ on day 16 and thereafter the medium was changed every three days with E199+10\% FCS. No antibiotics or antimycotics were used. The cultures were placed in a humidified, gassed $\left(5 \% \mathrm{CO}_{2}\right)$ incubator and maintained at $37^{\circ} \mathrm{C}$. For each experiment the lens epithelium was divided into 8 or more segments, half of which acted as controls while the remaining half were used for the test, thereby eliminating age variations that might have occurred between lenses. Each explant was cultured separately and cell proliferation was measured by calculating the number of cells in the outgrowth as previously described. ${ }^{16}$ Human neural retinal extract was added to the test cultures at a concentration of $6.4 \mu \mathrm{g}$ protein $/ \mathrm{ml}$ of culture medium and was present throughout the culture period.

\section{(c) Mathematical Modelling of Cell Growth}

Cell growth is best expressed in terms of population doubling since this is independent of the absolute number of cells. To investigate the dynamics of cell growth we used the Gompertz Growth Function to model the data. This function is an accepted method of quantifying cell growth and has been applied to normal and neoplastic growth ${ }^{17,18}$ and to HLE explants. ${ }^{16}$

The Gompertz Growth Function is expressed as

$$
\mathrm{N}_{\mathrm{t}}=\mathrm{N}_{\mathrm{o}} \exp \left(\mathrm{A} / \mathrm{r}\left(1-\mathrm{e}^{-\mathrm{rt}}\right)\right)
$$

where $\mathrm{N}_{\mathrm{t}}=$ number of cells at time, $\mathrm{t}$

$\mathrm{N}_{\mathrm{o}}=$ initial number of cells at $\mathrm{t}=0$

$\mathrm{A}=$ specific growth rate constant

$\mathrm{r}=$ retardation constant.

Values for the constant $\mathrm{A}$ and $\mathrm{r}$ may be determined by an iterative computation, using the least squares method so that equation (1) has the best fit to the observed results.

The Population Doubling Level (PDL) is an index of the number of population doublings that occur within a given time, $t$. It must be distinguished from cell doublings since PDL refers to the number of doublings undergone by the whole population, and because cells may drop out of the cell cycle due to contact inhibition, the actual number 
of cell cycles will be greater than the PDL. The time interval for each successive population doubling increases until growth ceases entirely when the maximum Population Doubling Level, $\mathrm{PDL}_{\max }$, is achieved and is expressed as

$\mathrm{PDL}_{\max }=\log _{10}\left(\mathrm{~N}_{\max } / \mathrm{N}_{\mathrm{o}}\right) \log _{10}{ }^{2}$

A more detailed treatment may be found in the work of Wright and Alison. ${ }^{19}$

\section{Results}

The explants were grown in culture for a period of 55 days. Outgrowth became visible

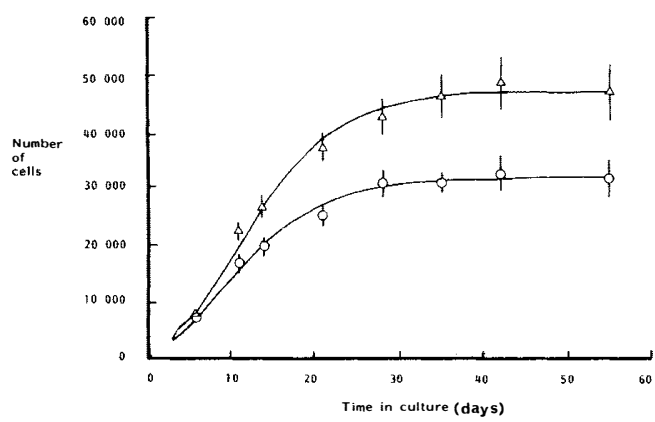

Fig. 1. The proliferation of cells from human lens epithelial explants in control conditions, $(\mathrm{O})$ and in medium enriched with neuro-retinal extract (NRE $6.4 \mathrm{ug} / \mathrm{ml}$ ) throughout the culture period $(\triangle)$. Each point represents the mean $(+/-S E)$ of 8 test and 8 control cultures from eyes 2 and 3, which were from the same donor. after 2-3 days after which the cells entered an exponential phase levelling off to a plateau after 25-30 days. No further increase in cell number was measured after this time although the cells continued to grow in size, particularly in the peripheral regions of the outgrowth. This increase was taken into account in the calculation of cell numbers.

Figure 1 shows data from eyes 2 and 3 which were from the same donor - thereby eliminating age differences. The total number of new cells produced by those cells exposed to NRE was $50 \%$ greater than those of the control cultures. Table I shows that the initial number of cells, $\mathrm{N}_{0}$, was slightly different between explants, therefore for accuracy the test and control cultures were compared in terms of $\mathrm{PDL}_{\max }$. This increased from a mean of 5.69 to 6.24 . In other words the effect of NRE is to stimulate an initial cell population, $\mathrm{N}_{\mathrm{o}}$, to grow to a final population of $\mathrm{N}_{0} \times 2^{6.24}$ as opposed to $\mathrm{N}_{\mathrm{o}} \times 2^{5.69}$ in control conditions.

In addition to increasing the total number of cells produced Figure 1 indicates that NRE increased the rate of growth, shown by the steeper growth curve. This is reflected in the mathematical model by an increase in the ratio $\mathrm{A} / \mathrm{r}$ (Table $\mathrm{I}$ ). Thus the first doubling time (i.e. $\mathrm{N}_{\mathrm{t}}=2 . \mathrm{N}_{0}$ ) is reduced from 1.37 days to 1.23 days.

In spite of the changes in the growth parameters there was no noticeable change in

Table I The effect of neuro-retinal extract (NRE) on the growth parameters of human lens epithelial explants.

\begin{tabular}{lllllllll}
\hline Conditions & & $\mathrm{N}_{\mathrm{o}}$ & $\mathrm{N}_{\max }$ & $\mathrm{A}$ & $\mathrm{r}$ & $\mathrm{A} / \mathrm{r}$ & $\mathrm{PDL}_{\max }$ & $(\mathrm{n})$ \\
\hline eye 1 & Control & 513 & 34,676 & 0.773 & 0.182 & 4.25 & $6.06 \pm .12$ & $(4)$ \\
& $+\mathrm{NRE}$ & 639 & 68,930 & 0.607 & 0.132 & 4.60 & $6.78 \pm .24$ & $(4)$ \\
eye 2 & Control & 763 & 32,605 & 0.547 & 0.145 & 3.72 & $5.36 \pm .18$ & $(4)$ \\
& + NRE & 759 & 48,325 & 0.558 & 0.134 & 4.16 & $5.86 \pm .24$ & $(4)$ \\
& & & & & & & & \\
eye 3 & Control & 754 & 31,036 & 0.575 & 0.155 & 3.97 & $5.30 \pm .26$ & $(4)$ \\
& +NRE & 750 & 46,136 & 0.641 & 0.155 & 4.14 & $5.94 \pm .06$ & $(4)$ \\
\multirow{2}{*}{ Mean } & Control & 677 & 32,772 & 0.632 & 0.161 & 3.98 & $5.69 \pm .13$ & $(12)$ \\
& + NRE & 716 & 54,464 & 0.602 & 0.140 & 4.30 & $6.24 \pm .17$ & $(12)$ \\
\hline
\end{tabular}

The values of Initial Cell Number, $\mathrm{N}_{\mathrm{o}}$, final cell number, $\mathrm{N}_{\max }$ ' Growth Constant, A, Retardation Constant, $r$, and Maximum Population Doubling Level, $\mathrm{PDL}_{\max }$, were determined as described. The values for eyes 1, 2 and 3 are presented as the mean of four cultures \pm standard error (number of experiments). 
the morphology of those cells exposed to NRE at any time during the 55 day culture period other than the senescent changes of peripheral cells also occurring under control conditions. At this stage the cells become enlarged, polymorphous, and in some cases vacuolated and polypoid. The appearance of multiple cytoplasmic filaments preceeded the migration of cells away from the explant until almost all the cells had separated from the explant and from each other.

\section{Discussion}

This study demonstrates the presence of an Eye Derived Growth Factor (EDGF) in human neuro-sensory retinal extract that is capable of increasing the growth rate and the proliferative capacity of adult human lens epithelial cells, without inducing differentiation into lens fibre cells. The stimuli by which EDGF acts is unknown. The Gompertz model illustrates three possibilities: firstly an increase in $\mathrm{A}$, the growth constant, second a decrease in $\mathrm{r}$, the retardation constant and third a combination of both. NRE raised the $\mathrm{A} / \mathrm{r}$ ratio from a mean of 4.0 to 4.3 . It is not possible to identify which of these constants is primarily effected. It is theoretically possible that test cultures responded to the NRE as a nutrient which had become depleted. We think this unlikely as the amount of medium used in all cultures was far in excess of their known requirements.

Our observation of the 5-8 day lag phase between the addition of the neuro-retinal extract to the test culture medium and increased cell growth rate is similar to that observed in studies on the incorporation of $3[\mathrm{H}]$ thymidine in bovine lens epithelial (BLE) cells. This is thought to indicate that the presence of EDGF is necessary for 48-72 hours before the label is incorporated into DNA. ${ }^{1}$

In this, and previous studies, ${ }^{14,16}$ it was not possible to achieve more than 7 population doublings. In studies on BLE cells ${ }^{4,13}$ far more generations of cells have been grown and it has been observed that in the absence of EDGF the epithelial cells become heterogeneous and enlarged and may elongate. Opacification of the posterior capsule following extracapsular extraction, with or without an implant is a common post-operative complication. ${ }^{20}$ It has been demonstrated by animal ${ }^{21}$ and post-mortem ${ }^{22}$ studies that a major contributory factor to this opacification is the proliferation of the lens epithelial cells which remain adherent to the residual anterior lens capsule. These cells, although normally in a non-proliferative state, are released from contact inhibition and could be available to re-enter the cell cycle. ${ }^{14}$

We have shown that there is a factor derived from human retina which enhances the proliferation of human lens epithelial cells in culture. Our retinal preparation was not a 'pure' growth factor and we have not investigated its relationship to previously described growth factors, for example, fibroblast growth factor. It is tempting to postulate that our retinal derived growth factor has a role in clinical situations such as posterior capsule opacification following cataract surgery.

This work was supported by the Wellcome Trust and the Humane Research Trust. T.J.C.J. is an MRC research fellow.

\section{References}

1 Arruti C and Courtois Y. Morphological changes and growth stimulation of bovine lens cells by a retinal extract. Exp. Cell Res. 1978; 117: 283-92.

2 Courtois Y, Arruti C, Barritault D, Tassin J, Olivie M Hughes R C. Modulation of the shape of epithelial cells in vitro directed by a retinal extract factor: a model of interconversion and the role of actin filaments and fibronectin. Differentiation 1981; 18: 11-27.

${ }^{3}$ Arruti C, Cirrilo A, Courtois Y. An eye derived growth factor regulates epithelial cell proliferation in the cultured lens. Differentiation 1985; 28: 286-90.

${ }^{4}$ Courtois Y, Arruti C, Barritault D, Courty J, Tassin J, Olivie M, Plouet J, Laurent $\mathbf{M}$, Perry $M$. The role of a growth factor derived from the retina (EDGF) in controlling the differentiated stages of several ocular and non ocular tissues. Adv. Exp. Med Biol. 1982; 158: 289-306.

${ }^{5}$ McAvoy J W and Fernon V T P. Neural retinas promote cell division and fibre differentiation in lens epithelial explants. Curr. Eye. Res. 1984; 3: 827-34.

${ }^{6}$ Campbell M T and McAvoy J W Onset of fibre differentiation in cultured rat lens epithelium 
under the influence of neural retina-conditioned medium. Exp. Eye Res. 1984; 39: 8394.

${ }^{7}$ Barritault D J, Plouet, J, Courty J Courtois Y. Purification, characterisation and biological properties of the eye derived growth factor from retina. Analogies with brain derived growth factor. Neurosci. Res. 1982; 8: 477-90.

8 Thompson P, Arruti C, Maurice D, Plouet J Barritault D Courtois Y. Angiogenic activity of a cell growth regulating factor derived from the retina, In: Clayton R, Haywood J, Reading $\mathrm{H}$ and Wright $\mathrm{A}$. (eds) Problems of normal and genetically abnormal retinas. London. Academic Press.

${ }^{9}$ Elstow S F, Schor A, Weiss J. Bovine retinal angiogenesis factor is a small molecule (molecular mas >600). Invest. Ophthalmol. Vis. Sci. 1985: 26; 74-9.

10 Gospodarowicz D, Mescher A, Brown K Birdwell C R. The role of fibroblastic and epidermal growth factor in the proliferative response of the cornea and lens epithelium. Exp. Eye Res. 1977: 25; 631-9.

11 Baird A, Esch F, Gospodarowicz D Guillemin R. Retina and eye derived endothelial growth factors: partial molecular characterisation and identity with acidic fibroblast growth factors. Biochemistry 1985; 24(27) 7855-60.

12 Baird A, Culler F, Jones K.1, Guillemin R. Angiogenic factor in human ocular fluid. Lancet 1985 ; ii 563 .

${ }^{13}$ Gospodarowicz D. and Massoglia S. Plasma fac- tors involved in the in vitro control of proliferation of bovine lens cells grown in defined medium. Effect of fibroblast growth factor on cell longevity. Exp Eye Res. 1982: 35; 259-70.

14 Jacob T J C, Humprhy R C, Davies, E G Thompson G M. Cytological factors relating to posterior capsule opacification following cataract surgery. Ophthalmol. 1987: 71; 65963.

15 Lowry O H, Rosebrough N J, Lewis Farr A Randall R J. Protein measurement with the folin phenol reagent. J. Biol. Chem. 1951; 193: $265-75$.

${ }^{16} \mathrm{Jacob}$ T J C. Human lens epithelial cells in culture: a quantitative evaluation of growth rate and proliferative capacity. Exp. Eye Res. 1987: 45; 93-104.

${ }^{17}$ Laird A K. Dynamics of tumor growth. Br. J. Cancer 1964; 18: 490-502.

${ }^{18}$ Laird A K. Dynamics of embryological growth. Growth 1966; 30: 263-75.

19 Wright N A and Alison M. The biology of epithelial cell populations. Vol 1; Clarendon Press, Oxford 1984: pp. 196-202.

${ }^{20} \mathrm{Jaffe}$ N S. Results of intraocular surgery. Am. J. Ophthalmol. 1978; 85: 13-23.

${ }^{21}$ Odrich M G, Hall S J, Worgul B V, Trokel S L, Rini F J. Posterior Capsule Opacification. Experimental Analysis. Ophthalmic Res. 1985; 17: 75-84.

22 Green W R, and McDonnel P J. Opacification of the Posterior Capsule. Trans. Ophthalmol. Soc. UK. 1985; 104: 727-39. 